\title{
432. Ergebnisse von Beinreplantationen
}

\author{
L. Zwank und P. Eckert
}

Kliniken der Stadt Saarbrücken, Winterberg, Akademisches Krankenhaus - Chirurgische Klinik, D-6600 Saarbrücken

\section{Results of Leg Replantation}

Summary. A follow-up in 12 cases of amputation of one or both legs and subsequent replantation showed that such patients have a good chance of rehabilitation, which will be improved still further as the operative technique is improved and the anoxemic period becomes shorter. Six of our patients returned to regular work, two to the same job, and three patients were able to walk more than $1,000 \mathrm{~m}$.

Key words: Leg replantation - Microsurgery - Vascular injuries - Injury, neurological.

Zusammenfassung. Eine Nachuntersuchung von 12 Fällen mit z.T. beidseitiger Beinamputation und nachfolgender Replantation aus dem eigenen Krankengut ergab, daß die bisherigen Ergebnisse ermutigend sind und durch Verkürzung der Anoxämiezeit sowie ausgefeiltere Operationstechnik noch verbessert werden können. 6 der Verletzten waren im Berufsleben wieder eingegliedert, 2 verrichteten die gleiche Arbeit wie zuvor, 3 Patienten erreichten eine Gehstrecke von über $1000 \mathrm{~m}$.

Schlüsselwörter: Beinreplantation - Mikrochirurgie - Gefäßverletzungen - Nervenverletzungen. 